\title{
Potentiation of the glycine response by serotonin on the substantia gelatinosa neurons of the trigeminal subnucleus caudalis in mice
}

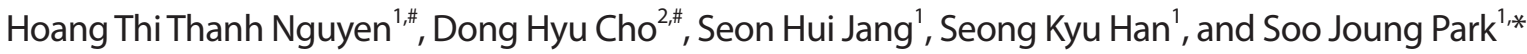 \\ ${ }^{1}$ Department of Oral Physiology, School of Dentistry and Institute of Oral Bioscience, Chonbuk National University, Jeonju 54896, ${ }^{2}$ Department of Obstetrics \\ and Gynecology, Chonbuk National University Hospital and School of Medicine, Jeonju 54896, Korea
}

\section{ARTICLE INFO}

Received April 5, 2019

Revised June 5, 2019

Accepted June 7, 2019

*Correspondence

Soo Joung Park

E-mail: soopark@jbnu.ac.kr

\section{Key Words}

Glycine receptor

Patch-clamp techniques

Serotonin

Substantia gelatinosa

\#These authors contributed equally to this work.

\begin{abstract}
The lamina II, also called the substantia gelatinosa (SG), of the trigeminal subnucleus caudalis $(\mathrm{Vc})$, is thought to play an essential role in the control of orofacial nociception. Glycine and serotonin (5-hydroxytryptamine, 5-HT) are the important neurotransmitters that have the individual parts on the modulation of nociceptive transmission. However, the electrophysiological effects of 5-HT on the glycine receptors on SG neurons of the Vc have not been well studied yet. For this reason, we applied the whole-cell patch clamp technique to explore the interaction of intracellular signal transduction between $5-\mathrm{HT}$ and the glycine receptors on SG neurons of the Vc in mice. In nine of 13 neurons tested (69.2\%), pretreatment with 5-HT potentiated glycine-induced current $\left(\mathrm{I}_{\mathrm{GI}}\right)$. Firstly, we examined with a $5-\mathrm{HT}_{1}$ receptor agonist (8-OH-DPAT, 5- $\mathrm{HT}_{1 / 7}$ agonist, co-applied with SB-269970, 5- $\mathrm{HT}_{7}$ antagonist) and antagonist (WAY-100635), but $5-\mathrm{HT}_{1}$ receptor agonist did not increase $\mathrm{I}_{\mathrm{Gly}}$ and in the presence of $5-\mathrm{HT}_{1}$ antagonist, the potentiation of $5-\mathrm{HT}$ on $\mathrm{I}_{\mathrm{Gly}}$ still happened. However, an agonist ( $\alpha$-methyl-5-HT) and antagonist (ketanserin) of the $5-\mathrm{HT}_{2}$ receptor mimicked and inhibited the enhancing effect of $5-\mathrm{HT}$ on $\mathrm{I}_{\mathrm{Gly}}$ in the SG neurons, respectively. We also verified the role of the $5-\mathrm{HT}_{7}$ receptor by using a $5-\mathrm{HT}_{7}$ antagonist (SB-269970) but it also did not block the enhancement of 5-HT on $\mathrm{I}_{\mathrm{Gly}}$. Our study demonstrated that $5-\mathrm{HT}$ facilitated $\mathrm{I}_{\mathrm{GI}}$ in the $\mathrm{SG}$ neurons of the $\mathrm{Vc}$ through the $5-\mathrm{HT}_{2}$ receptor. The interaction between $5-\mathrm{HT}$ and glycine appears to have a significant role in modulating the transmission of the nociceptive pathway.
\end{abstract}

\section{INTRODUCTION}

As one of the important neurotransmitters in the central nervous system (CNS), serotonin (5-hydroxytryptamine, 5 -HT) is concerned in nociceptive transmission through regulation of the descending pathways in the spinal level initiating in the rostral ventromedial medulla (RVM) [1-3]. Serotonergic projections from nucleus raphe magnus to the spinal cord dorsal horn are recognized to modulate pain sensations $[2,4,5]$.

Pain from the orofacial area to the trigeminal subnucleus caudalis $(\mathrm{Vc})$ is transmitted by sensory fibers, including the thin myelinated $\mathrm{A} \delta$ - and unmyelinated C-fibers [6,7], which innervate in the lamina I and much of lamina II (substantia gelatinosa, SG) $[8,9]$ of the Vc. The Vc, also called the medullary dorsal horn $(\mathrm{MDH})$, which resembles the spinal dorsal horn in both structure and function, is a key element in nociceptive transmission [10]. Therefore, the SG of the Vc is considered to contribute an essential role in the control of orofacial nociceptive encoding to the higher brain centers [11].

Glycine, the main inhibitory neurotransmitter in the CNS, is

\section{(i) (8)}

This is an Open Access article distributed under the terms of the Creative Commons Attribution Non-Commercial License, which permits unrestricted non-commercial use, distribution, and reproduction in any medium, provided the original work is properly cited. Copyright $\odot$ Korean J Physiol Pharmacol, pISSN 1226-4512, elSSN 2093-3827
Author contributions: H.T.T.N. performed experiments and analysis the data. S.H.J. contributed analysis partially. S.K.H. and S.J.P. conceptualized and designed the study. H.T.T.N., D.H.C., and S.J.P. drafted and wrote the final manuscript. 
also present in high concentrations in the SG neurons $[12,13]$. In the spinal dorsal horn and the medullary dorsal horn, glycine inhibits the glutamate-induced depolarization and attenuates the firing of the dorsal horn neurons $[14,15]$. Inhibitory glycinergic neurotransmission has been shown to have a principal role in the processing of nociceptive events from the periphery to higher brain areas $[16,17]$. Recently, many physiological studies reported that the functional features of glycine receptor-mediated outcomes were changed by phosphorylation of the glycine receptor through intracellular second messenger-triggered protein kinases [1820]. In contrast, several second messengers such as cyclic-3',5'adenosine monophosphate (cAMP), diacylglycerol, inositol1,4,5-trisphosphate, and $\mathrm{Ca}^{2+}$ has been studied to be paired with the serotonin (5-HT) receptor [21]. In addition, 5-HT has been demonstrated to potentiate the inhibitory effects of glycine in some types of neurons, such as rat sacral dorsal horn commissural neurons [22] and the superficial laminal neurons of the rat spinal dorsal horn [23]. However, electrophysiological proof of the 5-HT influence on the glycine receptors on SG neurons of the Vc has not been well established yet. Therefore, in the present study, a whole-cell patch clamp technique was performed to explore the interaction through the intracellular signal transduction between 5-HT and glycine receptors on SG neurons.

\section{METHODS}

\section{Brain slice preparation}

All experiment protocol on living animals described below was approved by the Institutional Animal Care Use Committee of Chonbuk National University (CBNU 2016-61). Immature male ICR mice (7-20 postnatal day) (Damul Science, Suwon, Korea) used in the present study were housed under 12-h light/ dark cycles (lights on at 06:00 h) with access to water and food ad libitum. The procedure to prepare brain slices was similar to our previous study [24]. After ICR mice were decapitated, their brains were taken out quickly and coronal slices (180-200 $\mu \mathrm{m}$ thick) including the MDH were cut using a vibratome (VT1200S; Leica biosystems, Wetzlar, Germany) in ice-cold artificial cerebrospinal fluid (ACSF). The components of ACSF were included (in $\mathrm{mM}$ ): $126 \mathrm{NaCl}, 2.5 \mathrm{KCl}, 2.4 \mathrm{CaCl}_{2}, 1.2 \mathrm{MgCl}_{2}, 11 \mathrm{D}$-glucose, 1.4 $\mathrm{NaH}_{2} \mathrm{PO}_{4}, 25 \mathrm{NaHCO}_{3}$ and 0.5 sodium ascorbate (pH 7.3 to 7.4 , bubbled with $95 \% \mathrm{O}_{2}$ and $5 \% \mathrm{CO}_{2}$ ). The slices were kept in welloxygenated ACSF before electrophysiological recordings were performed at room temperature for at least $1 \mathrm{~h}$.

\section{Electrophysiology}

Each brain slice was transferred into the recording chamber, submerged, and continuously perfused with oxygenated ACSF adjusted the flow at the rate of $4-5 \mathrm{ml} / \mathrm{min}$. An upright micro- scope (BX51WI; Olympus, Tokyo, Japan) with Nomarski differential interference contrast optics was used to observe the slices. The SG (lamina II) of the MDH was identified obviously as a translucent band just medial to the spinal trigeminal tract that went along the lateral fringe of the slice.

Membrane current recordings were carried out using the whole-cell patch clamp recording mode of an Axopatch 200B (Molecular devices, Union City, CA, USA). A Flaming/Brown micropipette puller (P-97; Sutter Instruments Co., Novato, CA, USA) with the thin-wall borosilicate glass-capillary tubing (PG52151-4; WPI, Sarasota, FL, USA) was used to pull the patch pipettes. The pipette solution contained the following (in $\mathrm{mM}$ ): $140 \mathrm{KCl}, 1 \mathrm{CaCl}_{2}, 1 \mathrm{MgCl}_{2}, 10$ HEPES, $4 \mathrm{MgATP}$, and 10 EGTA ( $\mathrm{pH} 7.3$ with $\mathrm{KOH})$. The resistance of the recording pipettes was 4-6 M $\Omega$. The membrane currents were sampled online by a Digidata $1322 \mathrm{~A}$ interface (Molecular devices) connected to a desktop computer. The signals were filtered $(2 \mathrm{kHz}$, Bessel filter of Axopatch 200B) before being digitized at a speed of $1 \mathrm{kHz}$. The holding potential was kept at $-60 \mathrm{mV}$ during the experiments. The mean holding current alterations within the control and treated period were measured as the mean of the peak-to-peak amplitude of individual points within each period. The acquisition and then subsequent analysis of the achieved data were processed by the Clampex 10.6 software (Molecular devices). All recordings were performed carefully at room temperature.

\section{Chemicals}

Glycine $(30 \mu \mathrm{M}), 5-\mathrm{HT}(10 \mu \mathrm{M})$, and the chemical substances for ACSF were bought from Sigma (St. Louis, MO, USA). SB$269970(10 \mu \mathrm{M}), 8-\mathrm{OH}-\mathrm{DPAT}(30 \mu \mathrm{M})$, WAY-100635 $(1 \mu \mathrm{M})$, ketanserin tartrate $(30 \mu \mathrm{M})$, and $\alpha$-methyl-5-HT maleate $(30 \mu \mathrm{M})$ were bought from Tocris Bioscience (Ellisville, MO, USA).

Stocks of all chemicals were made according to their solubility in distilled water, except SB-269970 and ketanserin tartrate, which were prepared in dimethyl sulfoxide. Stock solutions were diluted to desired final concentrations in ACSF immediately before cell treatment. Chemicals were applied to the neurons via bath application.

\section{Data and statistical analyses}

The traces were plotted using Origin 7 software (OriginLab Corp., Northampton, MA, USA). All values were represented as the mean \pm standard error of the mean. A paired t-test was applied to compare the mean amplitudes of the inward currents between the two groups. A p-value $<0.05$ was defined to be statistical significance level. 


\section{RESULTS}

The voltage clamp recordings were got from 41 SG neurons that belonged to 30 male ICR mice with 7-20 postnatal day.

\section{Potentiation of the $\mathrm{I}_{\mathrm{Gly}}$ response by $5-\mathrm{HT}$}

To investigate whether there were any changes in the glycineinduced inward current $\left(\mathrm{I}_{\mathrm{Gly}}\right)$ by 5-HT, we compared the responses elicited by glycine $(30 \mu \mathrm{M})$ alone and glycine with the simultaneous application of 5-HT $(10 \mu \mathrm{M})$. Firstly, repeated glycine applications at 5-min time interval showed that there was no difference between the first and second applications. In the next step, brain slice was pretreated with 5-HT for approximately $10 \mathrm{~min}$, then glycine was applied. The successive application of glycine in the attendance of 5-HT enlarged the $\mathrm{I}_{\mathrm{Gly}}$ (Fig. 1A). This potentiation was shown in the plurality of the neurons tested ( 9 of 13 neurons, 69.2\%) (in four remaining neurons, $\mathrm{I}_{\mathrm{Gly}}$ in the presence of 5-HT did not change when compared with $\mathrm{I}_{\mathrm{Gly}}$ alone). There was no significant difference between the mean inward currents by the first and second applications of glycine $(71.5 \pm 15.7 \mathrm{pA}$ and $73.5 \pm 14.9$ $\mathrm{pA}$, respectively, $\mathrm{n}=9 ; \mathrm{p}>0.05)$. In contrast, the mean amplitude of $\mathrm{I}_{\mathrm{Gly}}$ was significantly potentiated by 5 -HT $(104 \pm 25.1 \mathrm{pA}, \mathrm{n}=$ 9; $\mathrm{p}<0.05$ ) (Fig. 1B). These results indicate that 5-HT partially potentiated the glycine-induced current on the SG neurons of the Vc.

\section{Identification of 5-HT receptor subtypes accountable for the potentiation of $I_{G l y}$}

5-HT functions on numerous receptor subtypes that have been distributed into seven distinct classes based on molecular biological and pharmacological studies $[25,26]$. Therefore, to detect which receptor subtypes manage the enhancement of $\mathrm{I}_{\mathrm{Gly}}$, several selective agonists and antagonists of 5-HT receptors in the SG neurons of the $\mathrm{Vc}$ were investigated.
Firstly, we examined a $5-\mathrm{HT}_{1}$ receptor agonist and antagonist (Fig. 2). 8-OH-DPAT, a 5- $\mathrm{HT}_{1 / 7}$ receptor agonist, was used. A previous study by Yang et al. [27] demonstrated that $5-\mathrm{HT}_{7}$ receptors were functionally represented in the SG neurons of the Vc, so we bath-applied SB-269970, a 5- $\mathrm{HT}_{7}$ antagonist, together with 8-OHDPAT to check the selective effects of the $5-\mathrm{HT}_{1}$ receptor. The representative trace shows that in the spontaneous presence of $30 \mu \mathrm{M} 8$ 8-OH-DPAT and $10 \mu \mathrm{M}$ SB-269970, the glycine receptormediated response was not increased (Fig. 2A). The bar graph illustrates that 8-OH-DPAT and SB-269970 did not have any significant effect on the enhancement of $\mathrm{I}_{\mathrm{Gly}}(85 \pm 16 \%$ of the control, $\mathrm{n}=4 ; \mathrm{p}>0.05$ ) (Fig. 2B). In addition, $1 \mu \mathrm{M}$ WAY-100635, a 5-HT selective antagonist, was co-applied with $30 \mu \mathrm{M}$ glycine and 10 $\mu \mathrm{M}$ 5-HT. As we anticipated, WAY-100635 did not show any influence on the potentiation of $\mathrm{I}_{\text {Gly }}$ by $5-\mathrm{HT}$ (Fig. 2C). The increase in $\mathrm{I}_{\mathrm{Gly}}$ was shown in seven of 10 neurons (70\%). As shown in the bar graph, 5-HT and WAY-100635 increased the $\mathrm{I}_{\mathrm{Gly}}$ to $133 \pm 6 \%$ of the control ( $p<0.01$ ) (Fig. 2D). This means that the enhancement of $5-\mathrm{HT}$ to $\mathrm{I}_{\mathrm{Gly}}$ was not mediated by the $5-\mathrm{HT}_{1}$ receptors.

In the next stage of the experiment, the role of the $5-\mathrm{HT}_{2}$ receptor by an agonist and antagonist were analyzed (Fig. 3). As we expected, $\alpha$-methyl 5 -HT, a $5-\mathrm{HT}_{2}$ receptor-selective agonist, reproduced the effect of 5-HT on the $\mathrm{I}_{\mathrm{Gly}}$. After pretreatment with $30 \mu \mathrm{M} \alpha$-methyl 5-HT for $10 \mathrm{~min}$, the glycine $(30 \mu \mathrm{M})$-induced inward current was potentiated (Fig. 3A). In nine neurons tested with the $5-\mathrm{HT}_{2}$ agonist, six neurons (66.7\%) showed the potentiation of $\mathrm{I}_{\text {Gly. }}$. As shown in the bar graph, $\alpha$-methyl 5-HT increased the $\mathrm{I}_{\mathrm{Gly}}$ to $150 \pm 18 \%$ of the control (p < 0.05) (Fig. 3B). Furthermore, when ketanserine, a $5-\mathrm{HT}_{2}$ receptor-selective antagonist, was co-supplied, the augmentative potency of 5-HT on $\mathrm{I}_{\mathrm{Gly}}$ was blocked (Fig. 3C). There was no detectable effect on the enhancement of glycine-induced inward current by pretreatment with 30 $\mu \mathrm{M}$ ketanserine and $30 \mu \mathrm{M} 5$-HT for $10 \mathrm{~min}$. There was no significant change between the averages of the relative amplitudes of $\mathrm{I}_{\mathrm{Gly}}$ and that of $\mathrm{I}_{\mathrm{Gly}}$ in the presence of ketanserine and 5-HT (98 \pm $7 \%$ of the control, $n=5 ; p>0.05$ ) (Fig. 3D). These results suggest
A

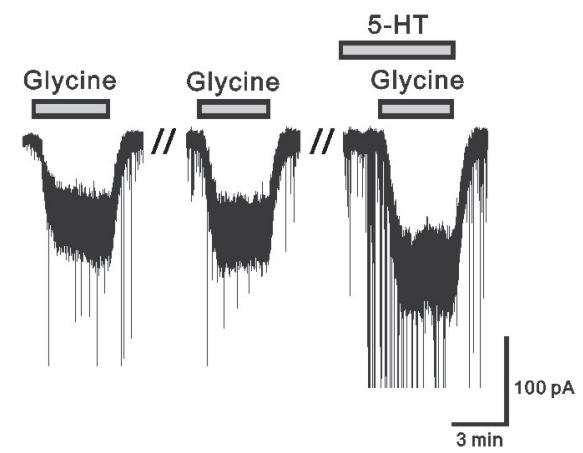

B

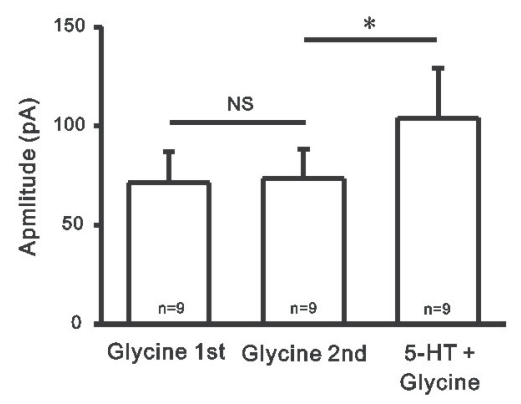

Fig. 1. Potentiation of glycine-induced current $\left(\mathrm{I}_{\mathrm{Gly}}\right)$ by 5 -hydroxytryptamine $(5-\mathrm{HT})$. (A) Representative trace shows the similarity of the repeated response induced by glycine $(30 \mu \mathrm{M})$ and then the facilitating effect of $5-\mathrm{HT}(10 \mu \mathrm{M})$ on $\mathrm{I}_{\mathrm{Gly}}$ in substantia gelatinosa neuron. (B) Bar graph compares the average values obtained repeated application of glycine and glycine in the presence of $5-\mathrm{HT}\left({ }^{*} \mathrm{p}<0.05\right)$. NS, not significant. 
A

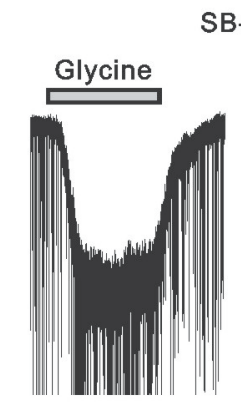

C

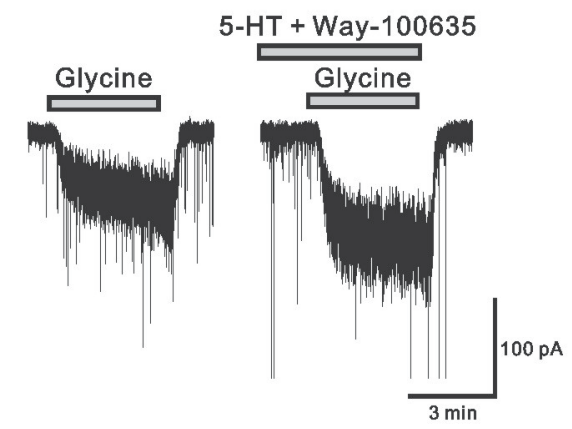

A

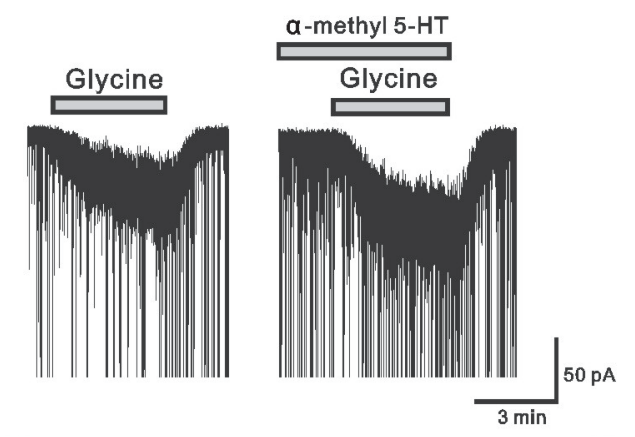

C

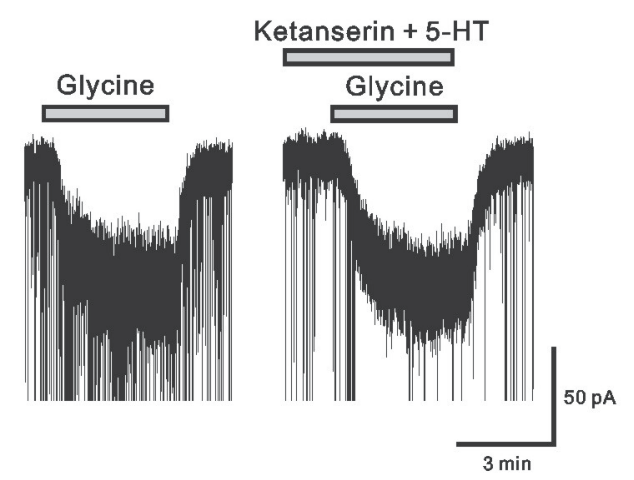

B

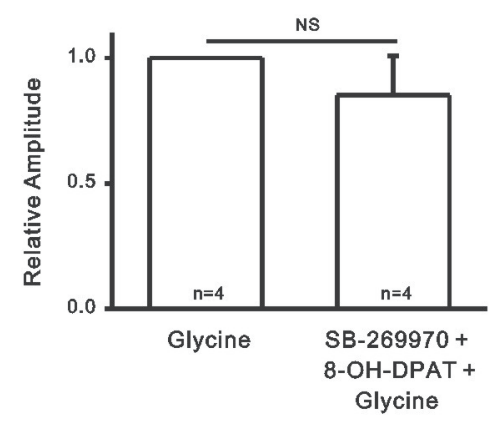

D

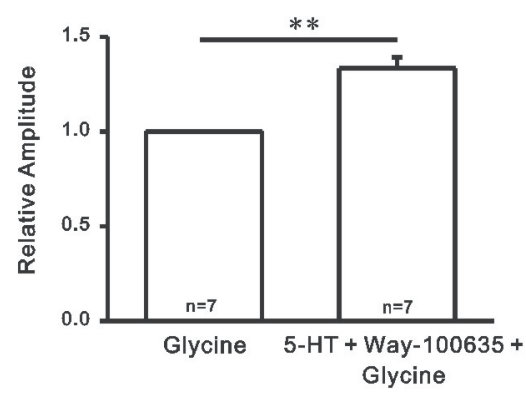

B
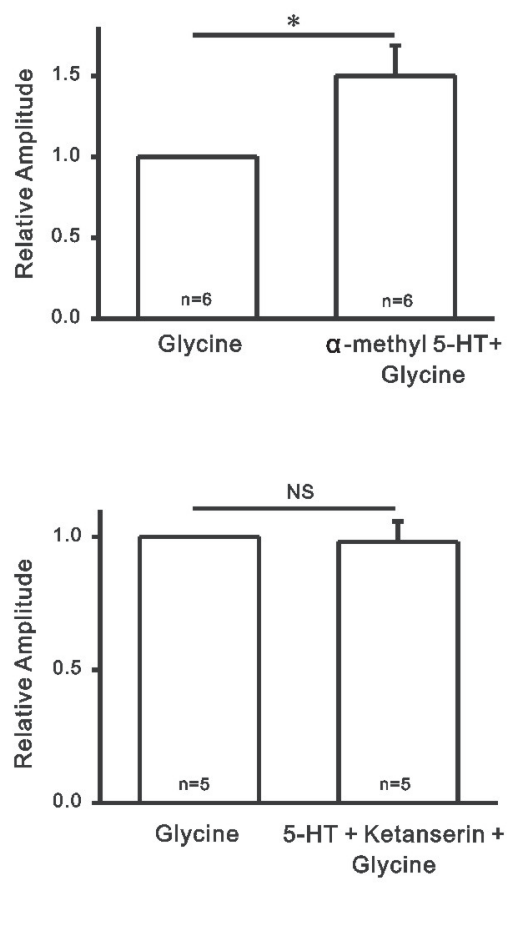

Fig. 2. Actions of 5-HT 1 agonist and antagonist on the 5-HT potentiation of glycine-induced current $\left(\mathrm{I}_{\mathrm{Gly}}\right)$. (A) The represent trace shows that $I_{G l y}$ was not increased in the presence of SB$269970(10 \mu \mathrm{M})$, a $5-\mathrm{HT}_{7}$ antagonist, and 8-OH-DPAT $(30 \mu \mathrm{M})$, a $5-\mathrm{HT}_{1 / 7}$ receptor agonist. (B) There was no significant difference between the mean relative amplitudes of $\mathrm{I}_{\text {Gly }}$ alone and $\mathrm{I}_{\mathrm{Gly}}$ with $5-\mathrm{HT}_{1}$ receptor agonist. (C) Glycine-induced inward current was increased by the simultaneous application of $5-\mathrm{HT}(10 \mu \mathrm{M})$ and WAY-100635 $(1 \mu \mathrm{M})$, a 5-HT, selective antagonist. (D) There is a significant difference between the mean values produced by glycine alone and that produced by glycine in the presence of 5-HT and WAY-100635 (**p < 0.01). 5-HT, 5-hydroxytryptamine; NS, not significant.
Fig. 3. Actions of $5-\mathrm{HT}_{2}$ agonist and antagonist on the 5 -HT potentiation of glycine-induced current $\left(\mathrm{I}_{\mathrm{Gly}}\right)$. (A) The represent trace showing $I_{\text {Gly }}$ was potentiated by $\alpha$-methyl $5-\mathrm{HT}(30 \mu \mathrm{M})$, a $5-\mathrm{HT}_{2}$ receptor-selective agonist. (B) Bar graph showing a statistical comparison of mean relative amplitudes between the application glycine $(30 \mu \mathrm{M})$ alone and glycine in the presence of $\alpha$-methyl 5-HT. (C) 5-HT $(10 \mu \mathrm{M})$ failed to potentiate $\mathrm{I}_{\mathrm{Gly}}$ in the presence of kentaserin $(30 \mu \mathrm{M})$, a $5-\mathrm{HT}_{2}$ receptor-selective antagonist. (D) Bar graph indicates no significant difference the mean relative amplitudes of $\mathrm{I}_{\text {Gly }}$ compared with $\mathrm{I}_{\mathrm{Gly}}$ with 5- $\mathrm{HT}_{2}$ antagonist ( $\left.{ }^{*} \mathrm{p}<0.05\right) .5-\mathrm{HT}, 5$-hydroxytryptamine; NS, not significant. that the activation of the $5-\mathrm{HT}_{2}$ receptor mostly contributed to the potentiation of $\mathrm{I}_{\mathrm{Gly}}$ by 5 -HT.

We also verified whether $5-\mathrm{HT}_{7}$ receptors had any involvement in the potentiation of $5-\mathrm{HT}$ on the $\mathrm{I}_{\mathrm{Gly}}$ (Fig. 4). We again used
$10 \mu \mathrm{M}$ SB-269970, a 5- $\mathrm{HT}_{7}$ antagonist, to co-apply with $30 \mu \mathrm{M}$ glycine and $10 \mu \mathrm{M} 5-\mathrm{HT}$. As the results from the experiments of $5-\mathrm{HT}_{1}$ receptors, $5-\mathrm{HT}_{7}$ also did not show any role on the potentiation of the glycine-induced inward currents. In the presence of 
A

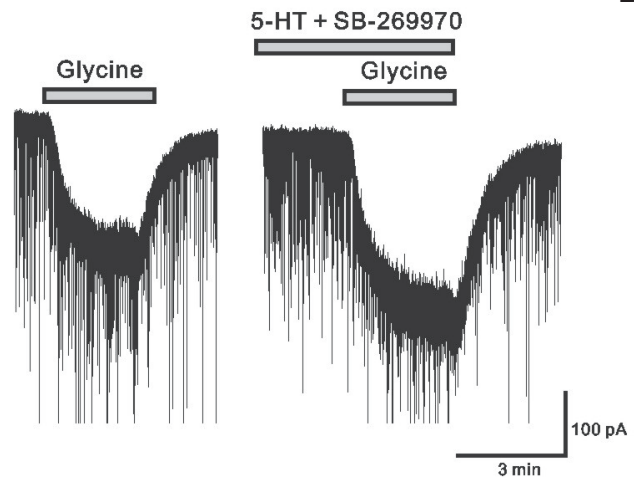

B

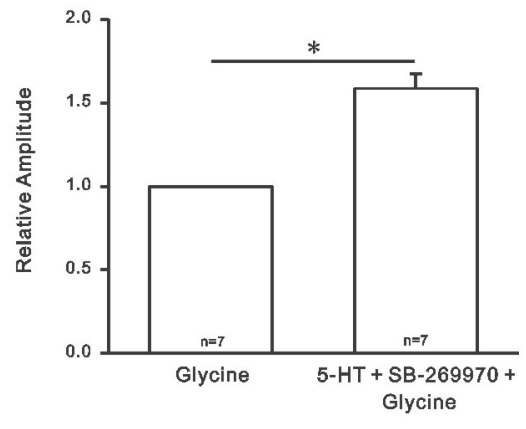

Fig. 4. Actions of $5-\mathrm{HT}_{7}$ receptors on the $5-\mathrm{HT}$ potentiation of glycine-induced current $\left(\mathrm{I}_{\mathrm{Gly}}\right)$. (A) The represent trace illustrates that the $\mathrm{I}_{\mathrm{Gly}}$ was still increased in the presence of both 5-HT $(10 \mu \mathrm{M})$ and SB-269970 $(10 \mu \mathrm{M})$, a 5- $\mathrm{HT}_{7}$ selective antagonist. (B) Bar graph demonstrates that there is a significant difference between the mean values created by glycine alone and by glycine in the simultaneous application of 5-HT and SB-269970 ( ${ }^{*} \mathrm{p}<0.01$ ). 5-HT, 5-hydroxytryptamine.

SB-269970, 5-HT still increased $\mathrm{I}_{\mathrm{Gly}}$ (Fig. 4A). This potentiation was shown in seven of 10 neurons (70\%). As demonstrated in the bar graph, 5-HT and SB-269970 increased the $\mathrm{I}_{\mathrm{Gly}}$ to $158 \pm 8 \%$ of the control ( $\mathrm{p}<0.01$ ) (Fig. 4B). These results help to exclude the potentiation of 5-HT to $\mathrm{I}_{\mathrm{Gly}}$ was mediated by $5-\mathrm{HT}_{7}$ receptors.

\section{DISCUSSION}

Glycine and 5-HT have been shown to apparently attenuate the activity of the spinal dorsal horn neurons [2,3,28]. Both these neurotransmitters have been demonstrated to be extensively innervated in the spinal dorsal horn by fibers descending from RVM or local inhibitory neurons. Stimulation of the ventromedial medulla evoked, either directly or indirectly, the co-release of glycine, as well as 5 -HT, and is possibly crucial for participating in RVM-spinal synaptic pathway [23,29].

The glycine receptor is a member of the ligand-gated ion channel family which can evoke inward current created via chloride conduction activation $[23,30]$. Study of the fundamental structure of glycine receptors has demonstrated that protein phosphorylation of these receptors could regulate their inhibitory function [31-33]. On the other hand, many reports have proposed that numerous neurotransmitters which adjust intracellular second messenger aspects can have the efficiently effect in the synaptic transmission by modulating the phosphorylation of ion channels $[20,31,34]$. And among those neurotransmitters, the 5-HT receptor has been recognized to be paired with second messengers. A variety of recent reports have shown that the potentiation of 5-HT on GABAergic neuronal activities [35-37]. Moreover, the co-localization of glycine and GABA in the same cell of the spinal dorsal horn has led to the suggestion that glycine and GABA could be activated as co-transmitters $[13,38]$. Therefore, the speculation that 5 -HT is also accountable for the increase of glycine releases in the spinal dorsal horn is reasonable. Our pres- ent results are consistent with this theory.

Phosphorylation is an important process which results in the alteration in the functional properties of the proteins. The main mechanism of this reaction is that the highly-charged phosphate group of ATP is added to a threonine, tyrosine, or serine side chains of a substrate protein [39]. Enzymes which catalyze for this covalent modification of a substrate protein are known as protein kinases. The glycine receptor, a ligand-gated ion channel protein, can be phosphorylated by second messenger-regulated proteins, such as cAMP-dependent protein kinase A (PKA) and protein kinase C (PKC) $[19,34,40]$. This operation seems to be a crucial mechanism for the modulation of the glycine receptor functions, for example raising the probability of channel opening, affecting the maximal chloride inflow, accelerating the desensitization, increasing the glycine receptor internalization rate via endocytosis, and changing the conformation of glycine binding-site [19,31,4143]. Both these protein kinases can alter the amplitude of glycine currents; however, the way of the modifications is not always consistent. These alterations clearly depend on the kind of cell and the experimental methodology. For instance, potentiation of $\mathrm{I}_{\mathrm{Gly}}$ after PKA activation was shown in neurons isolated from spinal trigeminal neurons [44], Xenopus oocytes isolated from nervous tissue [19], and trigeminal neurons isolated from lower medulla [45] of rats but the same application of PKA reduced $\mathrm{I}_{\mathrm{Gly}}$ in the rat ventromedial hypothalamic neurons [46]. Similarly, PKC has been reported to enhance $\mathrm{I}_{\mathrm{Gly}}$ in cultured hippocampal [18] and trigeminal neurons [45] of rats but to decrease $\mathrm{I}_{\text {Gly }}$ in rat oocyte expression systems $[19,47]$. The facilitation of 5 -HT on glycineinduced current has been demonstrated through the mediation of PKC in sacral dorsal commissural neurons [22] and in the superficial laminal neurons of the rat spinal dorsal horn [23]. Multiple PKC isoenzymes were shown to be plentiful in the lamina II of the rat spinal cord through autoradiographic and immunohistochemical studies $[48,49]$. Further research needs to be undertaken to ascertain which type of intracellular protein kinase modulates 
the potentiation of the glycine response by $5-\mathrm{HT}$ in the SG neurons of the Vc.

Structurally, glycine receptors are created by a combination of five distinct transmembrane protein subunits, four $\alpha$ subunits $(\alpha 1-\alpha 4)$ and one $\beta$ subunit. Each receptor subunit includes a large extracellular N-terminal domain, four transmembrane spanning domains (term TM1-TM4), and a long intracellular loop connecting TM3 and TM4 (TM3-4) [50]. This intracellular loop consists of the residues which are important for the phosphorylation process $[19,51]$. More detail, the process has been reported to activate the $\alpha$ subunit of the glycine receptor at the serine 391 residue located in the cytoplasmic TM3-4 loop in response to either PKA or PKC activators in intact spinal cord neurons [19]. However, the phosphorylation site is not always the same which may result from the different subunit composition of glycine receptor in various types of cells. For instance, PKC appears to phosphorylate the glycine $\alpha 1$ subunit at the serine residue S391 [51], while PKA has been shown to phosphorylate the serine residue sited in the $\alpha 1^{\text {ins }}$ and $\alpha 3$ subunit [41,52]. Besides, the glycine $\beta$-subunit isolated from rat spinal cord also hold a PKA consensus location in the TM3-4 domain at the position T363 [32]. On the other hand, lately, an additional PKC phosphorylation place (serine residue S403) was found in the $\beta$-subunits of mice spinal cord neurons [53].

Molecular cloning has classified 5-HT receptors into seven groups (from 5- $\mathrm{HT}_{1}$ to $5-\mathrm{HT}_{7}$ ), all of which are G-protein-coupled receptors, apart from the $5-\mathrm{HT}_{3}$ receptor subtype (ligandgated ion channel) [25]. Many 5-HT receptor subtypes have been detected in the $\mathrm{Vc}$, including $5-\mathrm{HT}_{1}, 5-\mathrm{HT}_{2}, 5-\mathrm{HT}_{3}$ and $5-\mathrm{HT}_{7}[27,54-56]$ and all of them could modulate transmission in the SG [57-59].

$5-\mathrm{HT}_{1}$ receptor was the first 5-HT receptor which the genomic clone was isolated in the human [60]. This subtype 5-HT receptor has a powerful affinity for 8-OH-DPAT [61]. $5-\mathrm{HT}_{1}$ receptor has been indicated to bind with numerous effectors, such as adenylyl cyclase, ion channels or protein kinase [62]. Electrophysiological studies have clearly indicated that $5-\mathrm{HT}_{1}$ in the spinal cord mediates inhibitory transmission of the nociceptive information $[63,64]$. Another subtype of the 5-HT receptor, 5- $\mathrm{HT}_{2}$ receptors, have been clone from diverse tissues and species [65]. This 5-HT binding level is very rich in layer IV of the neocortex, claustrum and olfactory tubercle; all other brain areas have a lower concentration of this receptor [66]. Structurally, 5- $\mathrm{HT}_{2}$ receptors are coupled to $\mathrm{Gq} / 11$ proteins which suggest excitatory effects [67,68]. Besides, some studies have been shown numerous distinct signaling pathways of $5-\mathrm{HT}_{2}$ receptors such as coupling to $\mathrm{Ca}^{2+}$ influx, intracellular $\mathrm{Ca}^{2+}$ release, activation PKC, and utilization phosphatidylinositol turnover $[69,70]$ which involved in the modulation of many molecular mechanisms. Especially, the $5-\mathrm{HT}_{3}$ receptors are designated as the class of peripheral 5-HT receptors because their pharmacological effects in the peripheral nervous system are distinct from $5-\mathrm{HT}_{1}$ and $5-\mathrm{HT}_{2}$ identified in the brain [71]. Latterly, $5-\mathrm{HT}_{3}$ has been also found in the mam- malian brain and spinal cord, with the highest concentration located in the region related to the vomiting reflex $[72,73]$. The stimulation these subtype receptors evoked excitatory responses due to their connection to nonselective cationic channel [63]. The $5-\mathrm{HT}_{3}$ receptor functions have been proved to be concerned with numerous aspects such as sensory processing, pain transmission, integration of the vomiting reflex and management of anxiety [74]. Finally, the last identified member of the big family of 5-HT is the $5-\mathrm{HT}_{7}$ receptor subtype, a G-protein-couple receptor which consists of seven transmembrane domains [25]. 5- $\mathrm{HT}_{7}$ receptor mRNA was detected both in the brain, mainly in the thalamus, hypothalamus, cortex, and hippocampus, and in the peripheral nervous system, mainly in the intestines and the blood vessels [75-77]. This receptor has been confirmed to link positively to adenylate cyclase, adding to the level of intracellular cAMP formation [77]. The operation of $5-\mathrm{HT}_{7}$ receptors which produces the anti-nociception results in the inhibition of nociceptive transmission $[27,68]$. Interestingly, it has been now known that $5-\mathrm{HT}_{7}$ and $5-\mathrm{HT}_{1}$ receptor share a relatively high-affinity agonist compound, 8-OH-DPAT, that leads to confusion concerning the complex functions of these two 5-HT receptor subtypes [78]. Our present study indicated that a $5-\mathrm{HT}_{1}$ and $5-\mathrm{HT}_{7}$ receptor had no significant effects on the potentiation of $\mathrm{I}_{\mathrm{Gly}}$ by 5 -HT. Nevertheless, the $5-\mathrm{HT}_{2}$ receptor selective agonist ( $\alpha$-methyl-5-HT) and antagonist (ketanserin) mimicked or blocked the potentiation effects of 5-HT on $\mathrm{I}_{\text {Gly }}$ respectively. This suggests that the $5-\mathrm{HT}_{2}$ receptor subtype was mostly accountable for the enhancement of $\mathrm{I}_{\mathrm{Gly}}$. Consistent with this observation, at the spinal level, there have been some reports which demonstrated that glycinergic transmissions were also augmented by activation of the $5-\mathrm{HT}_{2}$ receptors $[22,23]$.

In summary, this study supplies fresh evidence that 5-HT facilitated $\mathrm{I}_{\text {Gly }}$ in the $\mathrm{SG}$ neurons through the $5-\mathrm{HT}_{2}$ receptor subtypes. This operation might occur via the phosphorylation process. Taken together, this is the first report to supporting a positive correlation between these two inhibitory neurotransmitters in the SG neurons of the Vc in mice. The descending 5-HT pathway which mediated by the RVM-spinal tract enhanced glycinergic effects through the $5-\mathrm{HT}_{2}$ receptor, resulting in modifying pain perception. In brief, our present study supplies additional learning into the complex mechanism of 5-HT on the modulation of nociceptive information in the SG neurons of the Vc.

\section{ACKNOWLEDGEMENTS}

This study was supported by Basic Research Program through the National Research Foundation of Korea (NRF) funded by Ministry of Science, ICT \& Future Planning (2015R1C1A1A02036793) and Ministry of Education (2015R1D1A3A01018700). 


\section{CONFLICTS OF INTEREST}

The authors declare no conflicts of interest.

\section{REFERENCES}

1. Urban MO, Gebhart GF. Supraspinal contributions to hyperalgesia. Proc Natl Acad Sci U S A. 1999;96:7687-7692.

2. Millan MJ. Descending control of pain. Prog Neurobiol. 2002;66: 355-474.

3. Suzuki R, Rygh LJ, Dickenson AH. Bad news from the brain: descending 5-HT pathways that control spinal pain processing. Trends Pharmacol Sci. 2004;25:613-617.

4. Light AR, Casale EJ, Menétrey DM. The effects of focal stimulation in nucleus raphe magnus and periaqueductal gray on intracellularly recorded neurons in spinal laminae I and II. J Neurophysiol. 1986;56:555-571.

5. Basbaum AI, Zahs K, Lord B, Lakos S. The fiber caliber of 5-HT immunoreactive axons in the dorsolateral funiculus of the spinal cord of the rat and cat. Somatosens Res. 1988;5:177-185.

6. Light AR, Perl ER. Spinal termination of functionally identified primary afferent neurons with slowly conducting myelinated fibers. J Comp Neurol. 1979;186:133-150.

7. Sugiura Y, Lee CL, Perl ER. Central projections of identified, unmyelinated (C) afferent fibers innervating mammalian skin. Science. 1986;234:358-361.

8. Lorenzo LE, Ramien M, St Louis M, De Koninck Y, Ribeiro-da-Silva A. Postnatal changes in the Rexed lamination and markers of nociceptive afferents in the superficial dorsal horn of the rat. J Comp Neurol. 2008;508:592-604.

9. Todd AJ. Anatomy of primary afferents and projection neurones in the rat spinal dorsal horn with particular emphasis on substance $\mathrm{P}$ and the neurokinin 1 receptor. Exp Physiol. 2002;87:245-249.

10. Sessle BJ. Acute and chronic craniofacial pain: brainstem mechanisms of nociceptive transmission and neuroplasticity, and their clinical correlates. Crit Rev Oral Biol Med. 2000;11:57-91.

11. Santos SF, Rebelo S, Derkach VA, Safronov BV. Excitatory interneurons dominate sensory processing in the spinal substantia gelatinosa of rat. J Physiol. 2007;581(Pt 1):241-254.

12. Mitchell K, Spike RC, Todd AJ. An immunocytochemical study of glycine receptor and GABA in laminae I-III of rat spinal dorsal horn. J Neurosci. 1993;13:2371-2381.

13. Todd AJ, Watt C, Spike RC, Sieghart W. Colocalization of GABA, glycine, and their receptors at synapses in the rat spinal cord. J Neurosci. 1996;16:974-982.

14. Willis WD Jr, Coggeshall RE. Functional organization of dorsal horn interneurons. In: Willis WD Jr, Coggeshall RE, editors. Sensory mechanisms of the spinal cord. 3rd ed. Boston: Springer; 2004. p.271-560.

15. Willcockson WS, Chung JM, Hori Y, Lee KH, Willis WD. Effects of iontophoretically released amino acids and amines on primate spinothalamic tract cells. J Neurosci. 1984;4:732-740.

16. Price TJ, Cervero F, de Koninck Y. Role of cation-chloride-cotransporters (CCC) in pain and hyperalgesia. Curr Top Med Chem. 2005;5:547-555.
17. Möhler H, Rudolph U, Boison D, Singer P, Feldon J, Yee BK. Regulation of cognition and symptoms of psychosis: focus on GABA(A) receptors and glycine transporter 1. Pharmacol Biochem Behav. 2008;90:58-64.

18. Schönrock B, Bormann J. Modulation of hippocampal glycine receptor channels by protein kinase C. Neuroreport. 1995;6:301-304.

19. Vaello ML, Ruiz-Gómez A, Lerma J, Mayor F Jr. Modulation of inhibitory glycine receptors by phosphorylation by protein kinase $\mathrm{C}$ and cAMP-dependent protein kinase. J Biol Chem. 1994;269:20022008.

20. Albarran FA, Roa JP, Navarrete R, Castillo R, Nualart F, Aguayo LG. Effect of protein kinase $\mathrm{C}$ activation on the glycine evoked $\mathrm{Cl}(-)$ current in spinal cord neurons. Brain Res. 2001;902:1-10.

21. Martin GR, Humphrey PP. Receptors for 5-hydroxytryptamine: current perspectives on classification and nomenclature. Neuropharmacology. 1994;33:261-273.

22. Xu TL, Nabekura J, Akaike N. Protein kinase C-mediated enhancement of glycine response in rat sacral dorsal commissural neurones by serotonin. J Physiol. 1996;496(Pt 2):491-501.

23. Li H, Kang JF, Li YQ. Serotonin potentiation of glycine-activated whole-cell currents in the superficial laminae neurons of the rat spinal dorsal horn is mediated by protein kinase C. Brain Res Bull. 2002;58:593-600.

24. Nguyen HT, Bhattarai JP, Park SJ, Lee JC, Cho DH, Han SK. Enhanced GABA action on the substantia gelatinosa neurons of the medullary dorsal horn in the offspring of streptozotocin-injected mice. J Diabetes Complications. 2015;29:629-636.

25. Hoyer D, Hannon JP, Martin GR. Molecular, pharmacological and functional diversity of 5-HT receptors. Pharmacol Biochem Behav. 2002;71:533-554.

26. Boess FG, Martin IL. Molecular biology of 5-HT receptors. Neuropharmacology. 1994;33:275-317.

27. Yang EJ, Han SK, Park SJ. Functional expression of $5-\mathrm{HT}_{7}$ receptor on the substantia gelatinosa neurons of the trigeminal subnucleus caudalis in mice. Brain Res. 2014;1543:73-82.

28. Yoshimura M, Nishi S. Primary afferent-evoked glycine- and GABA-mediated IPSPs in substantia gelatinosa neurones in the rat spinal cord in vitro. J Physiol. 1995;482(Pt 1):29-38.

29. Sorkin LS, McAdoo DJ, Willis WD. Raphe magnus stimulationinduced antinociception in the cat is associated with release of amino acids as well as serotonin in the lumbar dorsal horn. Brain Res. 1993;618:95-108.

30. Langosch D, Becker CM, Betz H. The inhibitory glycine receptor: a ligand-gated chloride channel of the central nervous system. Eur J Biochem. 1990;194:1-8.

31. Swope SL, Moss SJ, Blackstone CD, Huganir RL. Phosphorylation of ligand-gated ion channels: a possible mode of synaptic plasticity. FASEB J. 1992;6:2514-2523.

32. Grenningloh G, Pribilla I, Prior P, Multhaup G, Beyreuther K, Taleb $\mathrm{O}$, Betz $\mathrm{H}$. Cloning and expression of the $58 \mathrm{kd}$ beta subunit of the inhibitory glycine receptor. Neuron. 1990;4:963-970.

33. Béchade C, Sur C, Triller A. The inhibitory neuronal glycine receptor. Bioessays. 1994;16:735-744.

34. Raymond LA, Blackstone CD, Huganir RL. Phosphorylation of amino acid neurotransmitter receptors in synaptic plasticity. Trends Neurosci. 1993;16:147-153.

35. Xu TL, Pang ZP, Li JS, Akaike N. 5-HT potentiation of the 
GABA(A) response in the rat sacral dorsal commissural neurones. Br J Pharmacol. 1998;124:779-787.

36. Li H, Lang B, Kang JF, Li YQ. Serotonin potentiates the response of neurons of the superficial laminae of the rat spinal dorsal horn to gamma-aminobutyric acid. Brain Res Bull. 2000;52:559-565.

37. Aghajanian GK, Marek GJ. Serotonin, via $5-\mathrm{HT}_{2 \mathrm{~A}}$ receptors, increases EPSCs in layer V pyramidal cells of prefrontal cortex by an asynchronous mode of glutamate release. Brain Res. 1999;825:161171.

38. Wang D, Li YQ, Li JL, Kaneko T, Nomura S, Mizuno N. $\gamma$-aminobutyric acid- and glycine-immunoreactive neurons postsynaptic to substance P-immunoreactive axon terminals in the superficial layers of the rat medullary dorsal horn. Neurosci Lett. 2000;288:187-190.

39. Edelman AM, Blumenthal DK, Krebs EG. Protein serine/threonine kinases. Annu Rev Biochem. 1987;56:567-613.

40. Breitinger U, Bahnassawy LM, Janzen D, Roemer V, Becker CM, Villmann C, Breitinger HG. PKA and PKC modulators affect ion channel function and internalization of recombinant alpha1 and alpha1-beta glycine receptors. Front Mol Neurosci. 2018;11:154.

41. Han L, Talwar S, Wang Q, Shan Q, Lynch JW. Phosphorylation of $\alpha 3$ glycine receptors induces a conformational change in the glycine-binding site. ACS Chem Neurosci. 2013;4:1361-1370.

42. Gentet LJ, Clements JD. Binding site stoichiometry and the effects of phosphorylation on human alpha1 homomeric glycine receptors. $J$ Physiol. 2002;544(Pt 1):97-106.

43. Huang R, He S, Chen Z, Dillon GH, Leidenheimer NJ. Mechanisms of homomeric alphal glycine receptor endocytosis. Biochemistry. 2007;46:11484-11493.

44. Song YM, Huang LY. Modulation of glycine receptor chloride channels by cAMP-dependent protein kinase in spinal trigeminal neurons. Nature. 1990;348:242-245.

45. Gu Y, Huang LY. Cross-modulation of glycine-activated Cl- channels by protein kinase $\mathrm{C}$ and cAMP-dependent protein kinase in the rat. JPhysiol. 1998;506(Pt 2):331-339.

46. Agopyan N, Tokutomi N, Akaike N. Protein kinase A-mediated phosphorylation reduces only the fast desensitizing glycine current in acutely dissociated ventromedial hypothalamic neurons. Neuroscience. 1993;56:605-615.

47. Uchiyama M, Hirai K, Hishinuma F, Akagi H. Down-regulation of glycine receptor channels by protein kinase C in Xenopus oocytes injected with synthetic RNA. Brain Res Mol Brain Res. 1994;24:295300 .

48. Worley PF, Baraban JM, Snyder SH. Heterogeneous localization of protein kinase $\mathrm{C}$ in rat brain: autoradiographic analysis of phorbol ester receptor binding. J Neurosci. 1986;6:199-207.

49. Nagashima T, Tanabe H, Fujioka Y, Nagashima K, Hidaka H. Immunohistochemical localization of protein kinase $\mathrm{C}$ isozymes in human cerebellum, hippocampus and spinal cord. Acta Histochem Cytochem. 1991;24:441-446.

50. Lynch JW. Molecular structure and function of the glycine receptor chloride channel. Physiol Rev. 2004;84:1051-1095.

51. Ruiz-Gómez A, Vaello ML, Valdivieso F, Mayor F Jr. Phosphorylation of the $48-\mathrm{kDa}$ subunit of the glycine receptor by protein kinase C. J Biol Chem. 1991;266:559-566.

52. Malosio ML, Grenningloh G, Kuhse J, Schmieden V, Schmitt B, Prior P, Betz H. Alternative splicing generates two variants of the alpha 1 subunit of the inhibitory glycine receptor. J Biol Chem. 1991; 266:2048-2053.

53. Specht CG, Grünewald N, Pascual O, Rostgaard N, Schwarz G, Triller A. Regulation of glycine receptor diffusion properties and gephyrin interactions by protein kinase C. EMBO J. 2011;30:38423853.

54. Doly S, Madeira A, Fischer J, Brisorgueil MJ, Daval G, Bernard R, Vergé $\mathrm{D}$, Conrath $\mathrm{M}$. The $5-\mathrm{HT}_{2 \mathrm{~A}}$ receptor is widely distributed in the rat spinal cord and mainly localized at the plasma membrane of postsynaptic neurons. J Comp Neurol. 2004;472:496-511.

55. Morales M, Battenberg E, Bloom FE. Distribution of neurons expressing immunoreactivity for the $5 \mathrm{HT}_{3}$ receptor subtype in the rat brain and spinal cord. J Comp Neurol. 1998;402:385-401.

56. Pompeiano M, Palacios JM, Mengod G. Distribution and cellular localization of mRNA coding for $5-\mathrm{HT}_{1 \mathrm{~A}}$ receptor in the rat brain: correlation with receptor binding. J Neurosci. 1992;12:440-453.

57. Yin H, Park SA, Han SK, Park SJ. Effects of 5-hydroxytryptamine on substantia gelatinosa neurons of the trigeminal subnucleus caudalis in immature mice. Brain Res. 2011;1368:91-101.

58. Grudt TJ, Williams JT, Travagli RA. Inhibition by 5-hydroxytryptamine and noradrenaline in substantia gelatinosa of guinea-pig spinal trigeminal nucleus. J Physiol. 1995;485(Pt 1):113-120.

59. Xie DJ, Uta D, Feng PY, Wakita M, Shin MC, Furue H, Yoshimura M. Identification of 5-HT receptor subtypes enhancing inhibitory transmission in the rat spinal dorsal horn in vitro. Mol Pain. 2012; 8:58.

60. Kobilka BK, Frielle T, Collins S, Yang-Feng T, Kobilka TS, Francke U, Lefkowitz RJ, Caron MG. An intronless gene encoding a potential member of the family of receptors coupled to guanine nucleotide regulatory proteins. Nature. 1987;329:75-79.

61. Middlemiss DN, Fozard JR. 8-Hydroxy-2-(di-n-propylamino)tetralin discriminates between subtypes of the $5-\mathrm{HT}_{1}$ recognition site. Eur J Pharmacol. 1983;90:151-153.

62. Raymond JR, Mukhin YV, Gelasco A, Turner J, Collinsworth G, Gettys TW, Grewal JS, Garnovskaya MN. Multiplicity of mechanisms of serotonin receptor signal transduction. Pharmacol Ther. 2001;92:179-212.

63. Abe K, Kato G, Katafuchi T, Tamae A, Furue H, Yoshimura M. Responses to 5-HT in morphologically identified neurons in the rat substantia gelatinosa in vitro. Neuroscience. 2009;159:316-324.

64. Ito A, Kumamoto E, Takeda M, Shibata K, Sagai H, Yoshimura M. Mechanisms for ovariectomy-induced hyperalgesia and its relief by calcitonin: participation of $5-\mathrm{HT}_{1 \mathrm{~A}}$-like receptor on $\mathrm{C}$-afferent terminals in substantia gelatinosa of the rat spinal cord. J Neurosci. 2000;20:6302-6308.

65. Kroeze WK, Kristiansen K, Roth BL. Molecular biology of serotonin receptors structure and function at the molecular level. Curr Top Med Chem. 2002;2:507-528.

66. Pazos A, Cortés R, Palacios JM. Quantitative autoradiographic mapping of serotonin receptors in the rat brain. II. Serotonin-2 receptors. Brain Res. 1985;346:231-249.

67. Sasaki M, Obata H, Saito S, Goto F. Antinociception with intrathecal alpha-methyl-5-hydroxytryptamine, a 5-hydroxytryptamine $2 \mathrm{~A} / 2 \mathrm{C}$ receptor agonist, in two rat models of sustained pain. Anesth Analg. 2003;96:1072-1078.

68. Seyrek M, Kahraman S, Deveci MS, Yesilyurt O, Dogrul A. Systemic cannabinoids produce $\mathrm{CB}_{1}$-mediated antinociception by activation 
of descending serotonergic pathways that act upon spinal 5- $\mathrm{HT}_{7}$ and 5- $\mathrm{HT}_{2 \mathrm{~A}}$ receptors. Eur J Pharmacol. 2010;649:183-194.

69. Conn PJ, Sanders-Bush E, Hoffman BJ, Hartig PR. A unique serotonin receptor in choroid plexus is linked to phosphatidylinositol turnover. Proc Natl Acad Sci U S A. 1986;83:4086-4088.

70. Cox DA, Cohen ML. 5- $\mathrm{HT}_{2 \mathrm{~B}}$ receptor signaling in the rat stomach fundus: dependence on calcium influx, calcium release and protein kinase C. Behav Brain Res. 1996;73:289-292.

71. Bradley PB, Engel G, Feniuk W, Fozard JR, Humphrey PP, Middlemiss DN, Mylecharane EJ, Richardson BP, Saxena PR. Proposals for the classification and nomenclature of functional receptors for 5-hydroxytryptamine. Neuropharmacology. 1986;25:563-576.

72. Miquel MC, Emerit MB, Nosjean A, Simon A, Rumajogee P, Brisorgueil MJ, Doucet E, Hamon M, Vergé D. Differential subcellular localization of the $5-\mathrm{HT}_{3}$-As receptor subunit in the rat central nervous system. Eur J Neurosci. 2002;15:449-457.

73. Tecott LH, Maricq AV, Julius D. Nervous system distribution of the serotonin 5- $\mathrm{HT}_{3}$ receptor mRNA. Proc Natl Acad Sci U S A. 1993;
90:1430-1434.

74. Färber L, Haus U, Späth M, Drechsler S. Physiology and pathophysiology of the 5- $\mathrm{HT}_{3}$ receptor. Scand J Rheumatol Suppl. 2004;119:2-8.

75. Ruat M, Traiffort E, Leurs R, Tardivel-Lacombe J, Diaz J, Arrang JM, Schwartz JC. Molecular cloning, characterization, and localization of a high-affinity serotonin receptor $\left(5-\mathrm{HT}_{7}\right)$ activating cAMP formation. Proc Natl Acad Sci U S A. 1993;90:8547-8551.

76. Lovenberg TW, Baron BM, de Lecea L, Miller JD, Prosser RA, Rea MA, Foye PE, Racke M, Slone AL, Siegel BW, Danielson PE, Sutcliffe JG, Erlander MG. A novel adenylyl cyclase-activating serotonin receptor $\left(5-\mathrm{HT}_{7}\right)$ implicated in the regulation of mammalian circadian rhythms. Neuron. 1993;11:449-458.

77. Bard JA, Zgombick J, Adham N, Vaysse P, Branchek TA, Weinshank RL. Cloning of a novel human serotonin receptor $\left(5-\mathrm{HT}_{7}\right)$ positively linked to adenylate cyclase. J Biol Chem. 1993;268:23422-23426.

78. Hedlund PB, Kelly L, Mazur C, Lovenberg T, Sutcliffe JG, Bonaventure P. 8-OH-DPAT acts on both $5-\mathrm{HT}_{1 \mathrm{~A}}$ and $5-\mathrm{HT}_{7}$ receptors to induce hypothermia in rodents. Eur J Pharmacol. 2004;487:125-132. 